\title{
Postharvest quality of 'Roxo de Valinhos' fig fruits grown in semi-arid conditions
}

\author{
'Federal Rural University of Semi-Arid, Mossoró, Brazil \\ ${ }^{2}$ Federal University of Lavras, Lavras, Brazil \\ *Corresponding author; e-mail: mickaelmedeiros@hotmail.com
}

Francisco Sidene Oliveira Silva', Eduardo Castro Pereira', Vander Mendonça' Elizangela Cabral dos Santos', Francisco Mickael de Medeiros Câmara*2, Gustavo Alves Pereira'

\begin{abstract}
Aiming to evaluate the postharvest quality of 'Roxo de Valinhos' fig fruits grown in semi-arid conditions, this experiment was carried out in November, 2014, where fig fruit variety 'Roxo de Valinhos' were harvested from plants located at the didactic orchard of the Federal Rural University of Semi-Arid (UFERSA), Mossoró-RN, Brazil. Fruits were randomly harvested from 30 fig plants, spaced $2 \mathrm{~m} \times 1.5$ $\mathrm{m}$, with 2 years old, according to three the fruit development stages $(50 \%, 75 \%$ and $100 \%$ mature). The fruits were analyzed in Postharvest Physiology Laboratory, where the physical and chemical characteristics were evaluated, using 10 fruits for each stage. The evaluated characteristics were: weight, length, diameter, firmness, soluble solids, $\mathrm{pH}$, titratable acidity and vitamin $\mathrm{C}$. For the physical characteristics, fruits $100 \%$ mature presented the best results for weight, length and diameter, except for firmness which in fruits $50 \%$ mature presented the best results. For the chemical characteristics, only the soluble solid variable was signiicant and fruits $100 \%$ mature showed the best result, in this way, the fig tree 'Roxo de Valinhos' achieved the postharvest fruit quality and is viable for the semiarid region of the Rio Grande Norte State.
\end{abstract}

Key-words: characterization, Ficus carica L, maturation, physico-chemic quality

\section{Qualidade pós-colheita de frutos de figueira 'Roxo de Valinhos' cultivados em condições semi-áridas}

\section{Resumo}

Objetivou-se avaliar a qualidade pós-colheita dos frutos de figueira 'Roxo de Valinhos' cultivados nas condições do semiárido do Rio Grande do Norte. O experimento foi realizado no mês de novembro de 2014, onde os frutos de figueira da variedade 'Roxo de Valinhos' foram colhidos de plantas do pomar didático da Universidade Federal Rural do Semiárido (UFERSA), no município de Mossoró-RN. Os frutos foram colhidos aleatoriamente de 30 plantas de figueira implantadas em espaçamento de $2 \mathrm{~m} \times 1,5 \mathrm{~m}$, com 2 anos de idade, de acordo com três estádios de desenvolvimento dos frutos (50\%, 75\% e 100\% maduros). Os frutos foram analisados no Laboratório de Fisiologia Pós-Colheita, onde foram avaliadas as características físicas e químicas, utilizando 10 frutos para cada estádio. As características avaliadas foram: peso, comprimento, diâmetro, firmeza, sólidos solúveis, pH, acidez titulável e vitamina C. Para as características físicas, os frutos $100 \%$ maduros apresentaram os melhores resultados para peso, comprimento e diâmetro, exceto para firmeza que obteve o melhor resultado nos frutos $50 \%$ maduros. Para as características químicas, apenas a variável sólido solúveis apresentou significância, sendo os frutos $100 \%$ maduros que resultaram no melhor resultado, dessa maneira, a figueira 'Roxo de Valinhos' se mostrou viável na qualidade dos frutos pós-colheita para a região do semiárido potiguar.

Palavras-chave: caracterização, Ficus carica L, maturação, qualidade físico-química 


\section{Introduction}

The fig (Ficus carica L.) belongs to the Moraceae family and consists of about 60 genders with over 2000 species, and in Brazil several species, wild and cultivated are present, with a domination of species with arboreal or shrubby growth habit, and with a rare presence of herbaceous plants(Paula et al., 2007).

Increased acreage and production of fruits in different Brazilian soil and climate regions is growing due to the modernization and significant improvements in the management of the rural property, factors of production and the adoption of low environmental impact technologies that provide quality and product safety to meet the requirements of the domestic consumer market and phytosanitary barriers from the importers (Fachinello et al, 2011; Retamales, 2011).

According to Paula et al. (2007), the fig tree 'Roxo de Valinhos' has great economic value characterized by its hardiness, vigor and yield. It is a plant that adapts very well to the drastic pruning system, moreover, the plants have large fruit, pear-shaped, elongated, with a short stalk, and dark purple external color as well as a purplish pink flesh color in the central cavity.

The desirable fruit postharvest quality are related to the maintenance of product characteristics such as texture, color, flavor and aroma and to minimize the deterioration in order to keep them attractive to the consumer as long as possible (LIMA et al., 1996). Physical and chemical characterization of fruits is important for the knowledge of the nutritional value, and from a commercial point of view, to add value and quality to the final product (CANUTO et al., 2010).

According to Gonçalves et al. (2006), several physical, chemical-physical, chemical and biochemical changes occur during fruit development, the growth pattern of the fruits can be studied by physical changes. In the formation of characteristics related to taste (mature figs) and industrialized fruit processing technology (immature figs), important changes in the composition of organic acids, carbohydrates and $\mathrm{pH}$ occurs.

In the case of temperate fruits, particularly the fig, the high perishability results in rapid transport need to consumption centers
(Lima et al., 2005). Some fruits, for presenting rapid senescence, prevent its storage for longer periods. This is of fundamental importance because it is difficult or even impossible for growers to send the fruit to more distant consumption centers (Paula et al., 2007).

There are few studies with fruit exotic flavors in the semiarid region, thus it is necessary to search for plants adapted to semi-arid conditions and provide a new option for commercial exploitation to growers. Thus, fig cv. 'Roxo de Valinhos' can allow greater diversification in the market and the use of the fruit for the production of fig jams, jellies and other products adding value to the crop.

Thus, the present study aimed to evaluate the postharvest behavior of 'Roxo de Valinhos' figs grown under the semi-arid conditions of the Rio Grande do Norte State, Brazil.

\section{Material and Methods}

The experiment was carried in November 2014, when fig fruits variety 'Roxo de Valinhos' were harvested from plants of the didactic orchard of the Federal Rural University of SemiArid (UFERSA) - Mossoró-RN, Brazil, located 511 1'15 " south latitude and 37 20'39" west longitude and altitude of 18 meters. The climate, according to Köppen classification, is the BSwh" type, hot and dry, with average annual rainfall of $673.9 \mathrm{~mm}$, temperature and average relative humidity of $27^{\circ} \mathrm{C}$ and $68.9 \%$, respectively; the rainy season in the region is from February to June, with very low possibility of rains between August and December (Carmo Filho and Oliveira, 1995). In Figure 1 the climatic data during the period of the experiment is presented.

Fruits were harvested randomly from 30 fig plants in three fruit development stages: stage 1 (50\% mature), stage 2 (75\% mature) and stage $3(100 \%$ mature), selected by size and fruit skin coloration, spaced $2 \times 1.5 \mathrm{~m}$, with 2 years old, which were conducted in drastic pruning system. After harvest, $300 \mathrm{~g}$ of fruit for each ripening stage were rinsed in pure water to prevent burning of the fruit by the action of ficin (enzyme present in the exudate latex after the fruit harvest).

Then, fruits were taken to the Postharvest Laboratory of the Physiology Department at 


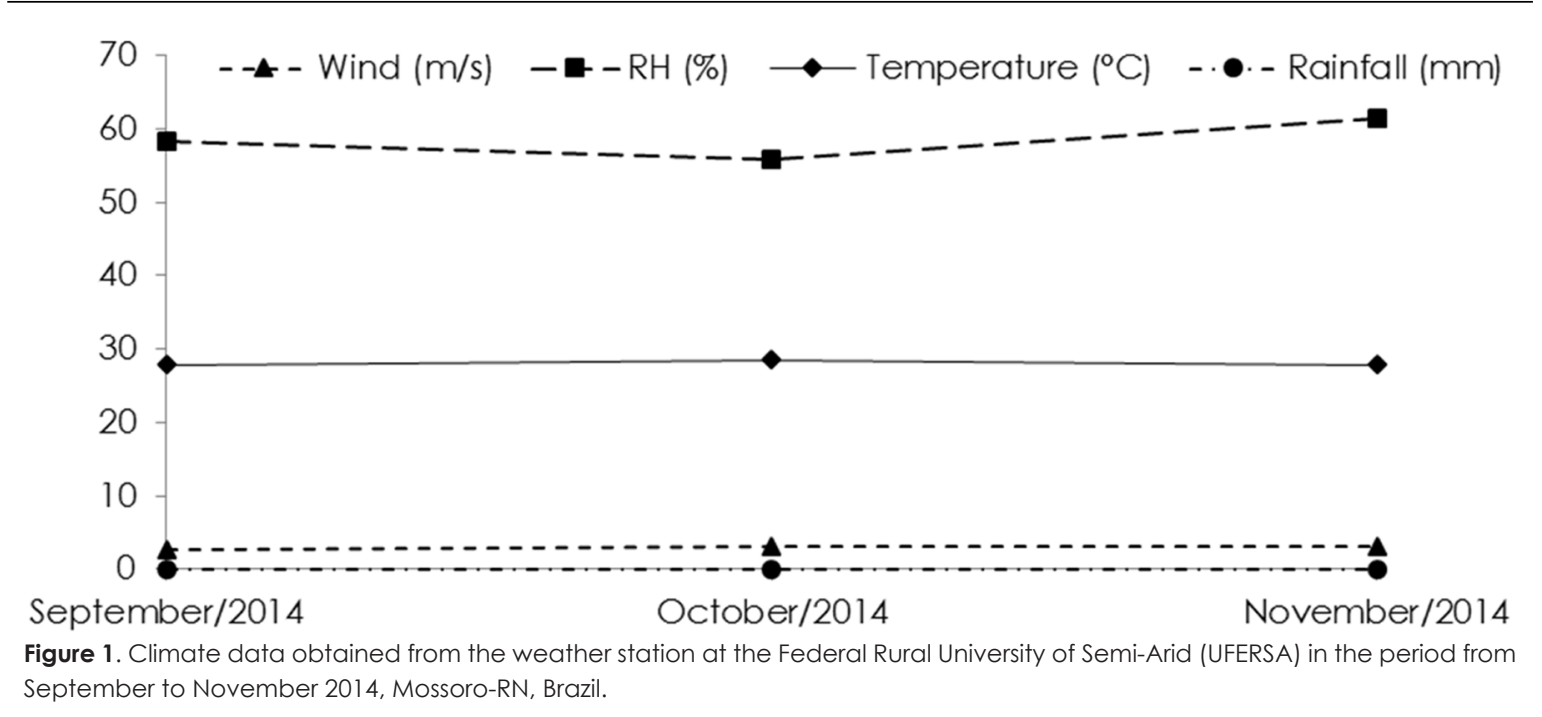

Federal Rural University of Semi-Arid (UFERSA), where the following physical and chemical characteristics were evaluated using 10 fruits in three maturity stages: weight, length, diameter, soluble solids, $\mathrm{pH}$, titratable acidity, firmness and vitamin C.

Weight was obtained by an analytical precision scale with four decimal places. The longitudinal length and diameter were obtained by measuring the fruit with the aid of a caliper and the results were converted into $\mathrm{cm}$.

The firmness was determined using a McCormick model FT 327 penetrometer, with 8 $\mathrm{mm}$ diameter cylindrical probe and penetration of $7 \mathrm{~mm}$ in the flesh and the evaluations were made on two equidistant regions and on the opposite sides of the equatorial region of the fruits, after removal of the skin and the readings were expressed in Lb.

The soluble solids (SST) in the juice was determined by a digital refractometer PR-100 Palette model (Attago Co. Ltd., Japan), with automatic temperature correction and the results expressed in percentage. The $\mathrm{pH}$ of the juice was determined, using a digital potentiometer, calibrated with buffer solutions of $\mathrm{pH} 4.0$ and 7.0.

Total Acidity was determined by the titration method using $1 \mathrm{~g}$ of sample in a $125 \mathrm{ml}$ Erlenmeyer flask, completing the volume with distilled water to $50 \mathrm{ml}$; adding 2 drops of $1 \%$ phenolphthalein and the titration was realized with $0.1 \mathrm{~N} \mathrm{NaOH}$ solution until slightly pink coloration. The calculations were performed and the results expressed as \% of malic acid. The vitamin C content was determined by titration with the indicator 2.6 - dichlorophenolindophenol, according to AOAC (2002).

The variables were submitted to analysis of variance and the means were grouped according to Tukey's test at $5 \%$ of probability with the aid of the SISVAR software (Ferreira, 2011).

\section{Results and Discussion}

According to the presented results, it was observed significant differences for weight, length, diameter, TSS and firmness, while for $\mathrm{pH}$, titratable acidity and vitamin $C$ there was no significant difference.

Regarding the average of fruit weight, an average of $32.17 \mathrm{~g}, 48.63 \mathrm{~g}$ and $52.09 \mathrm{~g}$ for the stages, 1, 2 and 3, respectively, with a significant difference for fruits from the stage 3 (Figure 2A). Similar results were observed by Nienow et al. (2006) with an average weight of $52.4 \mathrm{~g}$ for 3 cycles of vegetation for the 'Roxo de Valinhos' variety in the city of Passo Fundo-RS, Brazil.

For the variable length of the fruit, according to Figure $2 \mathrm{~B}$, it was observed that the stage 1 presented the lower value, with $3.83 \mathrm{~cm}$ and means for stages 2 and 3 did not differed significantly. The results obtained for fruit length is out of the range of diameters found by Rodrigues et al. (2012), working with selection of fig cv clones. 'Roxo de Valinhos' is formed by irradiated gemstones, where values ranging from 2.5 to 7.0 $\mathrm{cm}$, with an average of $4.88 \mathrm{~cm}$.

For fruit diameter, the stage 1 presented the better results, with an average of $4.23 \mathrm{~cm}$. Stages 2 and 3 did not differed, but the stage 3 

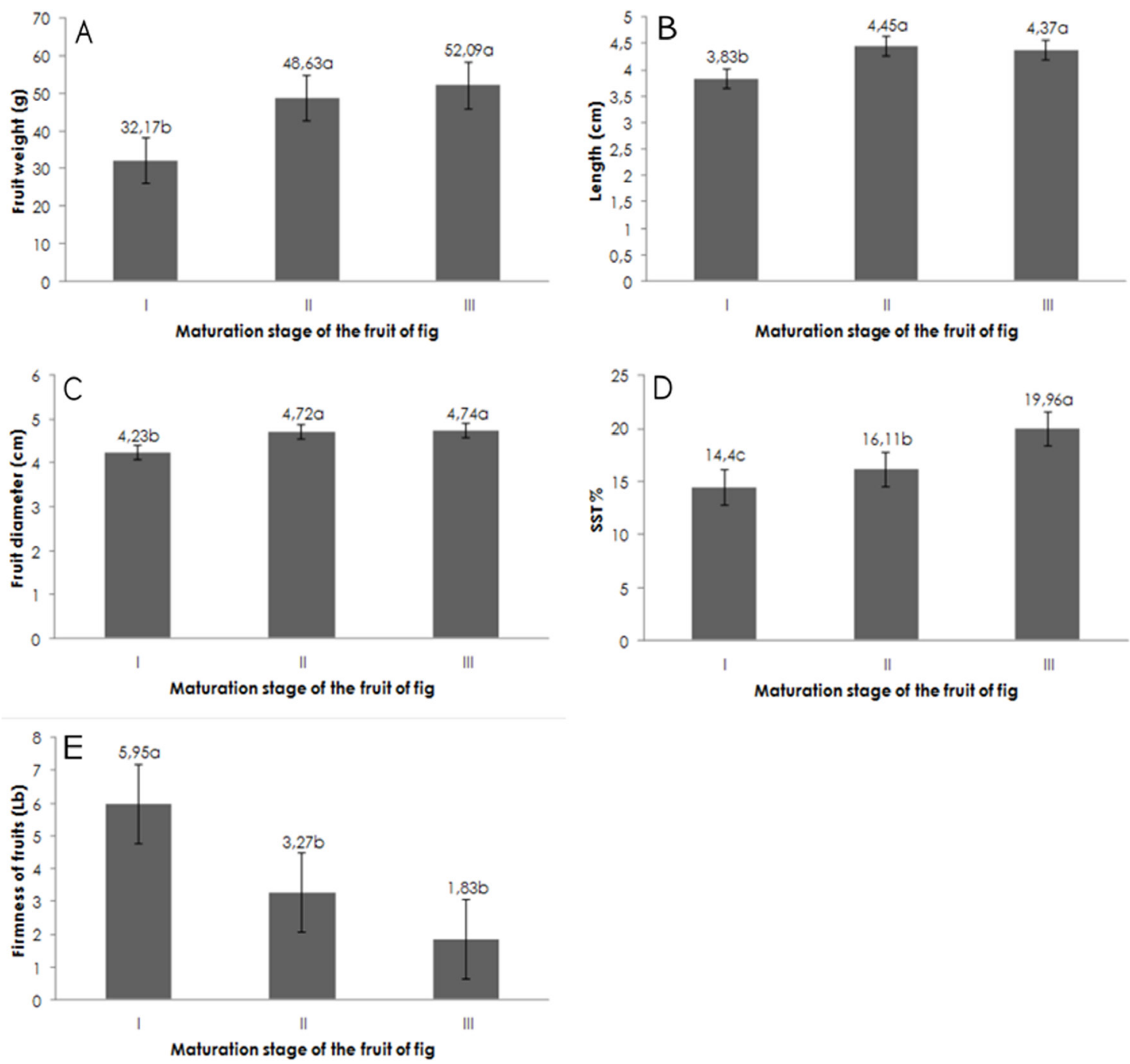

Figure 2. Average weight (A), length (B), diameter (C), soluble solids - SST (D) and firmness (E) of fruits of cV. 'Roxo de Valinhos' in three development stages (50, 75 and 100\% mature). Mossoro -RN, Brazil, 2015.

presented fruits with better results, $4.74 \mathrm{~cm}$ (Figure $2 \mathrm{C})$. This result is in agreement with the described by Rodrigues et al. (2012), with higher average to mature fruit, which presented a diameter ranging from 2.5 to $5.5 \mathrm{~cm}$ and an average of $4.24 \mathrm{~cm}$.

As can be observed in Figure 2D, total soluble solids (SST) showed an increase for the different maturity stages, with means of 19.96, 16.11 and $14.4 \%$ for the stages 3,2 and 1 respectively. As the fruit reaches maturity, the values tend to increase, confirming the results obtained in this study.

These values are higher than those founded by Gonçalves et al. (2006a), Gonçalves et al. (2006b), Leonel \& Tecchio (2008) and Fronza et al. (2010), studying the fig fruit quality for different Brazilian regions, with maximum values of $13 \%$.
The climatic conditions (Figure 1) present in the region of the study can explain the higher SST observed in this study, generating high brightness, increasing photosynthetic capacity of the plants and better sugar translocation from the leaves to the fruit, being a relative sourcedrain.

For $\mathrm{pH}$, although no significant in fruit development stages, values between 1.28 and 1.39 was observed, which are lower when compared to studies of Goncalves et al. (2006), Eidam et al. (2014) and Freitas et al. (2015). No statistical difference was observed for acidity according to fig ripening stages, however, the highest percentage of acidity was observed on stage 1 of maturation, which corresponded to $0.57 \%$, as opposed to fruit in stage 3 , which corresponded to $0.39 \%$. 
Freitas et al. (2015), evaluating the postharvest figs characterization under different conditions in the Apodi Tableland - Céara, Brazil, also found no significant response to the acidity, however, the values were lower than those observed in the present study $(0.114 \%$ and $0.161 \%$ ). Paula et al. (2007) testing the application of calcium chloride and fungicides, observed similar, but lower values that ranged from 0.17 to $0.26 \%$.

It is found that the soil and weather conditions affect the quality of fig fruit. Higher brightness is a major factor on the quality of fruits and many authors cite the effects on the fruit postharvest. According to Detoni et al. (2009), the fruit quality indices influenced by light include the size, the strength, the concentration of soluble solids, acidity, skin color and the content of vitamin C, among others.

Regarding the fruit firmness (Figure 2E), stage 1 presented the highest value $(5.96 \mathrm{Lb})$ and for stages 2 and 3 (3.27 and 1.83 Lb) the values were statistically similar. These values are in accordance to those normally observed for figs, since the enzymes action in the first stage is still incipient when compared to the ripening stage 3 .

Similar results were founded by Pinto et al. (2013), which observed a loss of firmness incamucamu (Myrciaria dubia) fruits, with increasing maturation of the fruit, where stage 1 (green fruit) presented higher firmness. The flesh softening can be attributed to the activity of hydrolytic enzymes such as polygalacturonase and pectin methyl esterase that promote intense solubilization of pectin, cell wall constituents, resulting in loss of firmness (Silva et al., 2009).

The firmness values observed in stage 1 were similar to the results founded by Eidam et al. (2014), studying different products in figs quality and ripening, which also observed the value of 5.0 Lb. The same author reports that fruits with greater firmness perform better in transportation and storage, being an important postharvest variable. Freitas et al. (2015) founded $1.12 \mathrm{Lb}$ to 35 days of figs from trees grown in different storage systems in Limoeiro do Norte-CE, Brazil, different for the values observed in this study. Firmness is one of the texture components of the fruits and an indicative of ripening. Besides the economic importance, since it affects the fruit quality, it must be taken into consideration the factors such as resistance to transport, shelf life, among others (BRAZ et al. 2008).

\section{Conclusions}

Stage 3 presented fig fruit with better results for weight, length, diameter and soluble solids content.

The fig tree 'Roxo de Valinhos' is viable, according to postharvest quality evaluation, for the semiarid region of the Rio Grande do Norte State, Brazil.

\section{References}

AOAC - Association of Official Analytical Chemists. 2002. Official methods of analysis of the AOAC. 17 ed. Washington.

Braz, V.B., Nunes, E. S., Vieira, G., Ribeiro Junior, J. I., Bertini, L.A., Couto, F.A.D. 2008. Indução do amadurecimento de mangas cv. Tommy Atkins e cv. Ubá pela aplicação de ethephon póscolheita. Bragantia, 67: 225-232.

Canuto, G.A.B, Xavier, A.A.O., Neves, L. C., Benassi, M. T. 2010. Caracterização físicoquímica de polpas de frutos da Amazônia e sua correlação com a atividade anti-radical livre. Revista Brasileira de Fruticultura, 32: 1196-1205.

Carmo Filho, F., Oliveira, O.F. 1995. Mossoró: um município do semiárido nordestino, caracterização climática e aspecto florístico. (Coleção Mossoroense, série B). Mossoró: ESAM, $62 \mathrm{p}$.

Detoni, A.M., Herzog, N.F.M., Ohland, T., Kotz, T. Clement, E. 2009. Influência do sol nas características fisicas e químicas da tangerina 'Ponkan' cultivada no oeste do Paraná. Ciência e Agrotecnologia, 33: 624-628.

Eidam, T., Spinardi, B., Ayub, R.A., Fonseca, L.G.B. 2014. Efeitos do óleo de soja e ácido 2-cloroetilfosfônico, na qualidade e na maturação de frutos de figo. Ambiência, 10:171-181.

Fachinello, J.C., Pasa, M.S., Schmitz, J.D., Betemps, D. L. 2011 . Situação e perspectivas da fruticultura de clima temperado no Brasil. Revista Brasileira de Fruticultura, 33:109-120.

Ferreira, D.F. 2011. Sisvar: A computer statistical analysis system. Ciência e Agrotecnologia, 35:1039-1042.

Freitas, R.N.S., Souza, P.A., Silva, M.E.T., Silva, F.L., Maracajá, P.B. 2015. Caracterização pós- 
colheita de figos (Ficus carica L.) produzidos sob diferentes condições de cultivo na Chapada do Apodi-CE. Revista Verde de Agroecologia e Desenvolvimento Sustentável, 10:43-46.

Fronza, D., Brackmann, A., Carlesso, R., Oliveira, A.R., Both, V., Pavanello, E.P., Hamann, J. 2010. Produtividade e qualidade de figos Roxo de Valinhos submetidos à fertirrigação e ao armazenamento refrigerado. Revista Ceres, 57:494-499.

Gonçalves, C.A.A., Lima, L.C.O., Lopes, P.S.N., Prado, M.E.T. 2006a. Caracterização física, físicoquímica, enzimática e de parede celular em diferentes estádios de desenvolvimento da fruta de figueira. Ciência e Tecnologia de Alimentos, 26:220-229.

Gonçalves, C.A.A., Lima, L.C.O., Lopes, P.S.N., Souza, M.T. 2006b. Poda e sistemas de condução na produção de figos verdes. Pesquisa Agropecuária Brasileira, 41:995-961.

Leonel, S., Tecchio, M.A. 2008. Produção de figueira submetida a diferentes épocas de poda e irrigação. Revista Brasileira de Fruticultura, 30:1015-1021.

Lima, L.C., Dias, M.S.C., Castro, M.V., Martins, R.N. Ribeiro Júnior, P.M., Silva, E.B. 2005. Conservação pós-colheita de figos verdes (ficus carica I.) $\mathrm{cv}$. Roxo de Valinhos tratados com hipoclorito de sódio e armazenados sob refrigeração em atmosfera modificada passiva. Ciência e Agrotecnologia, 29:810-816.

Nienow, A.A., Chaves, A., Lajús, C.R., Calvete, E.O. 2006. Produção da figueira em ambiente protegido submetida a diferentes épocas de poda e número de ramos. Revista Brasileira de Fruticultura, 28:421-424.

Paula, L.A., Isepon, J.S., Corrêa, L.S. 2007. Qualidade pós-colheita de figos do cv. Roxo-de - Valinhos com aplicação de cloreto de cálcio e fungicidas. Acta Scientiarum Agronomy, 29:4146.

Pinto, P.M., Jacomino, A.P., Silva, S.R. da, Andrade, C.A.W. 2013. Ponto de colheita e maturação de frutos de camu-camu colhidos em diferentes estádios. Pesquisa Agropecuária Brasileira, 48:605:612.

Rodrigues, M.G.F., Corrêa, L.S., Santos, P.C., Tulmann Neto, A. 2012. Seleção de clones de figueira cv. Roxo de Valinhos formados por gemas irradiadas. Revista Brasileira de Fruticultura, 34:604-611.

Silva, P.A., Abreu, C.M.P. de, Correa, A.D., Asmar, S.A. 2009. Modificações nas atividades da poligalacturonase e pectinametilesterase em morangos armazenados à temperatura

\section{ambiente. \\ Ciência \\ e \\ Agrotecnologia, 33:1953-1958.}

